\title{
PERAN PROFITABILITAS DALAM MEMEDIASI PENGARUH TINGKAT SUKU BUNGA DAN LEVERAGE TERHADAP RETURN SAHAM
}

\author{
I Gusti Ngurah Wira Aditya ${ }^{1}$ \\ Ida Bagus Badjra²
}

\author{
${ }^{1,2}$ Fakultas Ekonomi dan Bisnis Universitas Udayana, Bali, Indonesia \\ e-mail: wiraaditya43@gmail.com
}

\begin{abstract}
ABSTRAK
Penelitian ini bertujuan untuk menganalisis pengaruh tingkat suku bunga terhadap profitabilitas, pengaruh leverage terhadap profitabilitas, pengaruh tingkat suku bunga terhadap return saham, pengaruh leverage terhadap return saham, pengaruh profitabilitas terhadap return saham, pengaruh tingkat suku bunga terhadap return saham melalui profitabilitas, pengaruh leverage terhadap return saham melalui profitabilitas. Penelitian ini dilakukan di perusahaan sub sektor konstruksi bangunan yang terdaftar di BEI dengan populasi 13 perusahaan dan sampel 7 perusahaan dengan metode purposive sampling. Teknik analisis data menggunakan analisis jalur dan uji sobel. Berdasarkan hasil analisis ditemukan bahwa tingkat suku bunga berpengaruh positif signifikan terhadap profitabilitas, leverage berpengaruh positif signifikan terhadap profitabilitas, tingkat suku bunga berpengaruh positif signifikan terhadap return saham, leverage berpengaruh positif signifikan terhadap return saham, profitabilitas berpengaruh positif tidak signifikan terhadap return saham, profitabilitas secara signifikan tidak mampu memediasi pengaruh tingkat suku bunga terhadap return saham, dan profitabilitas secara signifikan tidak mampu memediasi pengaruh leverage terhadap return saham.
\end{abstract}

Kata kunci: tingkat suku bunga, leverage, profitabilitas, return saham

\begin{abstract}
The aim of this research is to analyze the influence of interest rate on profitability, the influence of leverage on profitability, the influence of interest rate on stock return, the influence of leverage on stock return, the influence of profitability on stock return, the influence of interest rate on stock return through profitability, the influence of leverage on stock return through profitability. This research is conducted on companies in the building construction sub sector listed in the Indonesian Stock Exchange with a total population of 13 companies and total sample is 7 companies determined using the purposive sampling method. The data analysis technique used is the path analysis and sobel test. Based on analysis results, it was found that interest rate has positive and significant influence on profitability, leverage has positive and significant influence on profitability, interest rate has positive and significant influence on stock return, leverage has positive and significant influence on stock return, profitability has positive but insignificant influence on stock return, profitability is significantly not capable of mediating the influence of interest rate on stock return, and profitability is significantly not capable of mediating the influence of leverage on stock return.
\end{abstract}

Keyword: interest rate, leverage, profitability, stock return 
I Gusti Ngurah Wira Aditya, Peran Profitabilitas dalam Memediasi...

\section{PENDAHULUAN}

Pada era globalisasi sekarang ini masyarakat lebih memilih mengelola dana yang dimilikinya dengan cara investasi di pasar modal. Pasar modal yaitu tempat bertemunya pihak investor dengan pihak emiten dengan melakukan menjual atau membeli sekuritas (Tandelilin, 2010:26). Keuntungan yang diperoleh dari investasi pada pasar modal dapat dilihat melalui return yang diperoleh dari saham yang diambil. Tandelilin (2010:102) mengatakan bahwa return ialah salah satu faktor yang mendorong para investor untuk berinvestasi serta kompensasi karena investor telah berani mengambil risiko dari investasi yang dilakukan.

Return saham mencerminkan kemampuan dari perusahaan dalam memakmurkan para pemegang saham. Perolehan return yang besar akan memberitahukan bahwa perusahaan tersebut mempunyai nilai yang baik serta keunggulan dalam berbisnis. Perusahaan yang memiliki keunggulan bisnis hingga memiliki prestasi yang bagus, jadi banyak investor yang berminat untuk melakukan investasi saham perusahaan tersebut. Prestasi yang didapat suatu perusahaan mampu dilihat dalam laporan keuangan yang dipublikasikan oleh perusahaan. Investor yang berinvestasi dengan membeli saham di pasar modal tentunya mengharapkan return yang tinggi. Harapan tersebut mampu terwujud apabila melakukan analisis serta upaya-upaya yang berhubungan dengan investasi sahamnya, karena hal tersebut perlu diketahui faktor-faktor yang dapat memengaruhi return saham. Faktor-faktor yang dapat memeengaruhi return saham diantaranya tingkat suku bunga, leverage, serta profitabilitas. 
Tingkat suku bunga dikatakan mampu memberikan dampak langsung terhadap kondisi perekonomian. Meningkatnya tingkat suku bunga akan mengakibatkan beban biaya perusahaan seperti biaya produksi akan meningkat pula, sehingga harga-harga produk yang ditawarkan perusahaan meningkat dan konsumen akan menunda pembeliannya dan menyimpan dananya. Pembelian yang ditunda akan menurunkan penjualan perusahaan dan akan menyebabkan penurunan laba perusahaan. Penelitian yang Simiyu and Ngile (2015) lakukan mendapatkan hasil yaitu tingkat suku bunga memiliki pengaruh negatif terhadap profitabilitas.

Tingkat suku bunga yang meningkat akan meningkatkan beban perusahaan, namun apabila perusahaan mampu mengatur pendanaan usahanya hingga menekan biaya-biaya yang dikeluarkan dan mampu meningkatkan penjualan maka akan meningkatkan laba perusahaan. Apabila laba yang diterima perusahaan lebih tinggi dibandingkan peningkatan tingkat suku bunga, sehingga laba bersih yang didapat meningkat dan profitabilitas perusahaan akan meningkat. Penelitian yang dilakukan oleh Khan and Sattar (2014), Malik et al. (2014) serta Ali (2015) mendapatkan hasil dimana tingkat suku bunga berpengaruh positif terhadap profitabilitas.

Investor yang ingin berinvestasi kerap memerhatikan laporan keuangan perusahaan, dari laporan keuangan tampak salah satu rasio keuangan yakni rasio leverage. Investor selalu memerhatikan rasio ini, dikarenakan rasio ini menghitung besarnya aktiva perusahaan dibiayai oleh hutang. Debt to equity ratio (DER) digunakan sebagai alat ukur dari leverage, sebab rasio ini menunjukkan persentase besarnya hutang yang digunakan oleh perusahaan. Ketika DER perusahaan sedikit, maka beban yang perlu dikeluarkan oleh perusahaan pun sedikit. Laporan mengenai 
adanya pemakaian hutang bagi perusahaan mampu membagikan laba kepada para investor berkat adanya pemakaian hutang tersebut, perusahaan mempunyai keadaan yang bagus dalam memperoleh profit (Effendi, 2013). Penelitian yang dilakukan oleh Herdiani dkk. (2014), Setiawan dan Triaryati (2016), serta Lindayani dan Dewi (2016) mendapatkan hasil bahwa leverage memiliki pengaruh positif terhadap profitabilitas.

Perusahaan yang tidak mampu mengoptimalkan operasi perusahaan dengan dana yang berasal dari hutang, menyebabkan penjualan dari perusahaan akan menurun. Penurunan dari penjualan tersebut mengakibatkan penurunan laba dari perusahaan. Penelitian yang Enekwe et al. (2014) serta Awan (2014) lakukan mendapatkan hasil bahwa leverage berpengaruh negatif terhadap profitabilitas.

Tingkat suku bunga yang meningkat tentu menjatuhkan nilai saat ini dari penerimaan dividen di masa datang, maka hal ini dapat menyebabkan turunnya harga saham di pasar modal (Saputra dan Dharmadiaksa, 2016). Menurunnya harga saham akan menyebabkan investor mengalami kerugian dalam menginvestasikan sahamnya di pasar modal. Penelitian yang Utami et al. (2015) lakukan menemukan hasil yaitu tingkat suku bunga mempunyai hubungan yang negatif dengan return saham. Riset yang Khan et al. (2012) dan Dewi dkk. (2016) lakukan mendukung hal tersebut yang menunjukkan hasil yang sama.

Tingkat suku bunga yang meningkat dikatakan akan menurunkan harga saham perusahaan. Menurut teori keynes, tingkat suku bunga yang meningkat akan membuat masyarakat menahan sedikit uang kas yang dimilikinya dan sebagian besar dana yang dimilikinya akan diinvestasikan pada saham atau surat berharga 
lainnya. Dimana investor mengamati pergerakan harga saham perusahaan yang mampu mendapatkan laba yang besar. Apabila tingkat suku bunga naik, investor akan mengamati laba bersih perusahaan dan memprediksi bahwa di masa mendatang perusahaan mampu mendapatkan laba yang besar, lalu investor akan menginvestasikan dananya di perusahaan yang akan menyebabkan harga saham perusahaan naik (Dewi dan Sudiartha, 2014). Peningkatan harga saham perusahaan akan menimbulkan return yang diperoleh meningkat. Bararoh (2015) menunjukkan hasil bahwa suku bunga memiliki pengaruh positif terhadap return saham.

Laba perusahaan yang menurun akibat dari ketidakmampuan dalam mengoptimalkan operasi perusahaan dengan menggunakan hutangnya akan menyebabkan dividen yang dibagikan kepada investor semakin kecil atau tidak dibagikan sama sekali. Penelitian yang dilakukan oleh Allozi and Obeidat (2016), Utami et al. (2015), Ghi (2016), dan Acheampong et al. (2014) membuktikan hal tersebut dengan menemukan hasil yaitu leverage memiliki pengaruh negatif terhadap return saham.

Perusahaan yang mampu mengoptimalkan operasi perusahaan dengan menggunakan dana dari hutangnya akan menyebabkan penjualan perusahaan meningkat, yang berarti laba perusahaan akan meningkat pula. Meningkatnya laba perusahaan akan membuat investor tertarik untuk melakukan investasi dan hal ini dapat menyebabkan harga perusahaan semakin meningkat. Penelitian yang Abdullah et al. (2015) lakukan menemukan hasil bahwa leverage dan return saham memiliki hubungan yang positif. 
I Gusti Ngurah Wira Aditya, Peran Profitabilitas dalam Memediasi...

Para investor pasti menginginkan keuntungan dari melakukan investasi, maka hal yang perlu diperhatikan investor yaitu rasio profitabilitas perusahaan. Return on equity (ROE) digunakan sebagai alat ukur dari profitabilitas, sebab ROE menggambarkan kesanggupan perusahaan dalam mewujudkan keuntungan pada para investor atas dana yang diinvestasikan di perusahaan (Tandelilin, 2010:245). Semakin tinggi ROE perusahaan, akan semakin bagus perusahaan tersebut menurut para investor serta hal ini mampu mengakibatkan harga saham perusahaan semakin naik. Penelitian yang Anwaar (2016), Khan et al. (2013), Allozi and Obeidat (2016), Ganerse dan Suarjaya (2014), serta Adiyadnya dkk. (2016) lakukan menemukan hasil dimana profitabilitas memiliki pengaruh positif terhadap return saham. Penelitian yang Mahmudah (2016) lakukan menemukan hasil yang berbeda yaitu profitabilitas berpengaruh tidak signifikan terhadap return saham.

Perubahan tingkat suku bunga akan mempengaruhi profitabilitas perusahaan (Maulida dkk, 2016). Tingkat suku bunga yang meningkat akan meningkatkan beban perusahaan, namun apabila perusahaan mampu mengatur pendanaan usahanya hingga menekan biaya-biaya yang dikeluarkan dan mampu meningkatkan penjualan maka akan meningkatkan laba perusahaan. Apabila laba yang diterima perusahaan lebih tinggi dibandingkan peningkatan tingkat suku bunga, dapat menaikkan laba bersih yang didapat dan profitabilitas perusahaan mampu meningkat. Meningkatnya laba perusahaan akan menarik perhatian para investor untuk menginvestasikan dana yang dimilikinya, dengan demikian akan mempengaruhi harga saham perusahaan. Peningkatan harga saham perusahaan menyebabkan return saham yang diperoleh investor mampu mengalami 
peningkatan pula. Hasil penelitian yang Maringka et al. (2016), Sari (2013), dan Widyastuti et al. (2017) lakukan menunjukkan bahwa profitabilitas signifikansi memediasi pengaruh tingkat suku bunga terhadap return saham.

Penggunaan hutang yang tinggi akan mengakibatkan laba perusahaan menurun, apabila perusahaan yang bersangkutan tidak menggunakan hutang yang dimilikinya secara tepat. Para investor yang tidak menyukai adanya risiko, maka akan menjauhi perusahaan yang mempunyai hutang yang besar. Perusahaan tentu akan berjuang untuk melunasi hutang yang dimilikinya sehingga laba perusahaan akan berkurang. Perusahaan yang dapat menggunakan hutang yang dimilikinya dengan benar selaku modal dalam tindakan operasionalnya, maka akan mampu menaikkan laba dan nilai saham perusahaan. Nilai perusahaan yang tinggi menggambarkan return yang para investor peroleh juga naik. Penelitian yang dilakukan oleh Setiawan dan Triaryati (2016), Al-fisah (2016), dan Nevada (2016) menunjukkan hasil bahwa profitabilitas signifikansi memediasi pengaruh leverage terhadap return saham.

Terdapat banyak sektor yang menggunakan pasar modal selaku sumber dananya, seperti sub sektor konstruksi bangunan. Sub sektor konstruksi bangunan mempunyai peran yang berpengaruh di dalam perekonomian negara, lantaran dapat memengaruhi sebagian besar sektor perekonomian negara dan sebagai kontributor yang penting bagi proses pembangunan.

Tabel 1.

Return Saham Perusahaan yang Termasuk dalam Sub Sektor Konstruksi Bangunan Periode 2011-2015

\begin{tabular}{llcccc}
\hline \multirow{2}{*}{ Nama Industri } & \multicolumn{5}{c}{ Tahun } \\
& 2011 & 2012 & 2013 & 2014 & 2015 \\
\hline
\end{tabular}


I Gusti Ngurah Wira Aditya, Peran Profitabilitas dalam Memediasi...

\begin{tabular}{cccccc}
\hline ACST & 0 & 0 & 0 & $0,87 \%$ & $-0,19 \%$ \\
ADHI & $0,49 \%$ & $0,49 \%$ & $-0,14 \%$ & $1,31 \%$ & $0,49 \%$ \\
DGIK & $0,49 \%$ & $0,49 \%$ & $0,04 \%$ & $0,49 \%$ & $0,53 \%$ \\
IDPR & 0 & 0 & 0 & 0 & 0 \\
JKON & $0,49 \%$ & $0,49 \%$ & $0,86 \%$ & $0,55 \%$ & $-0,01 \%$ \\
MTRA & 0 & 0 & 0 & 0 & 0 \\
NRCA & 0 & 0 & 0 & $0,73 \%$ & $-0,46 \%$ \\
PBSA & 0 & 0 & 0 & 0 & 0 \\
PTPP & $-0,39 \%$ & $0,49 \%$ & $0,40 \%$ & $2,08 \%$ & $0,08 \%$ \\
SSIA & $0,49 \%$ & $0,50 \%$ & $0,55 \%$ & $0,55 \%$ & $0,33 \%$ \\
TOTL & $0,12 \%$ & $0,49 \%$ & $0,19 \%$ & $0,49 \%$ & $0,12 \%$ \\
WIKA & $0,10 \%$ & $1,43 \%$ & $0,07 \%$ & $0,49 \%$ & $-0,28 \%$ \\
WSKT & 0 & 0 & $-0,10 \%$ & $0,63 \%$ & $0,17 \%$ \\
\hline
\end{tabular}

Sumber:www.duniainvestasi.com (data diolah, 2017)

Berdasarkan tabel 1. dapat diketahui bahwa return saham perusahaan konstruksi bangunan mengalami fluktuasi setiap tahunnya. Berdasarkan fenomena return saham sub sektor konstruksi bangunan di Bursa Efek Indonesia (BEI) periode 2011-2015 serta terdapat research gap di penelitian sebelumnya antara pengaruh tingkat suku bunga terhadap return saham dan pengaruh leverage terhadap return saham, maka penelitian ini perlu dilakukan.

Berdasarkan penjelasan sebelumnya, tedapat tujuh pokok permasalahan yang akan diperjelas dalam penelitian ini. Ketujuh masalah tersebut diantaranya (1) Bagaimanakah signifikansi pengaruh tingkat suku bunga terhadap profitabilitas?; (2) Bagaimanakah signifikansi pengaruh tingkat suku bunga terhadap return saham?; (3) Bagaimanakah signifikansi pengaruh leverage terhadap profitabilitas?; (4) Bagaimanakah signifikansi pengaruh leverage terhadap return saham?; (5) Bagaimanakah signifikansi pengaruh profitabilitas terhadap return saham?; (6) Apakah pengaruh tingkat suku bunga terhadap return saham dapat dimediasi oleh profitabilitas?; (7) Apakah pengaruh leverage terhadap return saham dapat dimediasi oleh profitabilitas? 
Berdasarkan permasalahan yang dijelaskan, maka penelitian ini bertujuan diantaranya (1) Dapat mengetahui signifikansi pengaruh tingkat suku bunga terhadap profitabilitas; (2) Dapat mengetahui signifikansi pengaruh tingkat suku bunga terhadap return saham; (3) Dapat mengetahui signifikansi pengaruh leverage terhadap profitabilitas; (4) Dapat memahami signifikansi pengaruh leverage terhadap return saham; (5) Dapat mengetahui signifikansi pengaruh profitabilitas terhadap return saham; (6) Dapat mengetahui pengaruh tingkat suku bunga terhadap return saham dapat dimediasi oleh profitabilitas; (7) Dapat memahami pengaruh leverage terhadap return saham dapat dimediasi oleh profitabilitas.

Pasar modal merupakan tempat untuk menjual atau membeli sekuritas yang biasanya mempunyai umur melebihi satu tahun, misalnya saham serta obligasi (Tandelilin, 2010:26). Pasar modal mempunyai fungsi selaku lembaga perantara (intermediaries), yang memperlihatkan posisi penting pasar modal untuk menunjang perekonomian sebab pasar modal mampu mempertemukan pihak yang memerlukan modal kepada pihak yang memiliki modal lebih (Tandelilin, 2010:26).

Return adalah hasil atas pengurangan dari harga saham sekarang dengan periode sebelumnya dan dibagi dengan harga saham periode sebelumnya (Brigham dan Houston, 2011:215). Investor ditujukan dengan ketidakpastian perolehan return dengan risiko yang dihadapinya. Return yang diperoleh investor di pasar modal terdapat dua jenis, antara lain dividen dan capital gain/loss. Dividen ialah keuntunan yang didapat dari pembayaran yang bersifat periodik. Return yang berupa capital gain/loss ialah selisih laba atau rugi yang investor alami, sebab harga saham sekarang lebih tinggi atau rendah dibandingkan harga saham sebelumnya. 
I Gusti Ngurah Wira Aditya, Peran Profitabilitas dalam Memediasi...

Rasio profitabilitas yaitu rasio yang memerlihatkan keterampilan perusahaan untuk memeroleh laba atau ukuran seberapa efektif perusahaan dalam mengelola manajemen perusahaan (Wiagustini, 2014:86). Profitabilitas memiliki makna penting untuk perusahaan sebab profitabilitas ialah salah satu dasar dalam menilai situasi perusahaan. Tingkat profitabilitas menunjukkan kemampuan perusahaan yang dilihat dari keterampilan perusahaan mencari laba. Keterampilan perusahaan dalam mencari laba memerlihatkan apakah perusahaan memiliki prospek yang bagus atau tidak di masa mendatang. Rasio profitabilitas yang digunakan dalam penelitian ini yaitu Return on Equity (ROE). Rasio ini memerlihatkan efisiensi penggunaan modal sendiri. Semakin besar ROE menggambarkan bahwa laba bersih yang diperoleh akan semakin besar.

Leverage yaitu keahlian perusahaan dalam melunasi kewajiban finansial jangka pendeknya dan jangka panjangnya atau menghitung seberapa besar perusahaan menggunakan hutang (Wiagustini, 2014:85). Perusahaan yang mempunyai rasio leverage yang kecil dalam menghadapi risiko kerugian yang dialami lebih kecil saat perekonomian sedang melemah, tetapi mempunyai tingkat return yang kecil pada saat perkonomian tinggi. Rasio leverage yang dipakai dalam penelitian ini ialah Debt to Equity Ratio (DER). Debt to equity ratio digunakan karena untuk melihat besarnya ekuitas dari para pemegang saham yang dipakai untuk menutupi keseluruhan utang perusahaan.

Tingkat suku bunga yang mengalami perubahan dapat mengakibatkan tingkat suku bunga yang diisyaratkan pada suatu sekuritas berubah (Tandelilin, 2010:343). Tingkat suku bunga yang sangat besar dapat memengaruhi nilai sekarang pada 
aliran kas perusahaan yang dapat menyebabkan kesempatan investasi yang ada dapat membuat para investor tidak tertarik. Data tingkat suku bunga yang dipakai disini yaitu tingkat suku bunga SBI.

Berdasarkan konsep-konsep yang dirujuk, dapat dijelaskan penelitian ini melalui gambar kerangka konseptual pada Gambar 1, sehingga dipergunakan untuk perumusan hipotesis dalam penelitian.

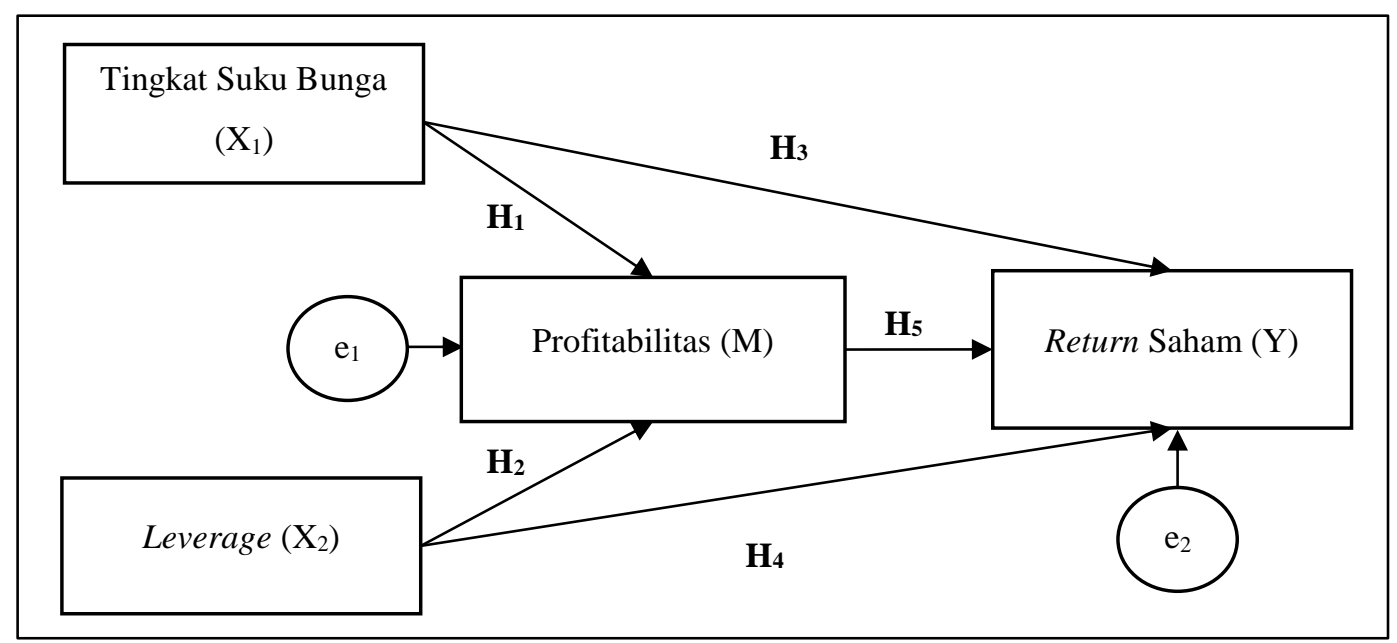

Gambar 1. Kerangka Konseptual Penelitian

Berdasarkan model kerangka penelitian pada Gambar 1. dapat dibuat 2 (dua) hipotesis lanjutan, yaitu:

H6 : Pengaruh tidak langsung $\left(\mathrm{X}_{1}\right)$ terhadap $(\mathrm{Y})$

$\mathbf{H}_{7}$ : Pengaruh tidak langsung $\left(\mathrm{X}_{2}\right)$ terhadap $(\mathrm{Y})$

\section{HIPOTESIS PENELITIAN}

\section{Pengaruh Tingkat Suku Bunga Terhadap Profitabilitas}

Suku bunga SBI ialah instrument suku bunga yang dipublikasikan oleh BI dalam mengatur penyebaran uang di masyarakat (Rismawati, 2014). Perubahan tingkat suku bunga akan mempengaruhi profitabilitas perusahaan. Tingkat suku bunga yang meningkat akan meningkatkan beban perusahaan, namun apabila 
perusahaan mampu mengatur pendanaan usahanya hingga menekan biaya-biaya yang dikeluarkan dan mampu meningkatkan penjualan maka akan meningkatkan laba perusahaan. Apabila laba yang diterima perusahaan lebih tinggi dibandingkan peningkatan tingkat suku bunga, dapat menaikkan laba bersih yang didapat dan profitabilitas perusahaan pun meningkat. Penelitian yang dilakukan oleh Khan and Sattar (2014), Malik et al. (2014), dan Ali (2015) mendukung hal tersebut yang mendapatkan hasil bahwa tingkat suku bunga memiliki pengaruh positif terhadap profitabilitas. Sementara itu, penelitian yang Simiyu and Ngile (2015) lakukan mendapatkan bahwa tingkat suku bunga memiliki pengaruh negative terhadap profitabilitas. Berdasarkan penelitian terdahulu, mampu disusun hipotesis yaitu: $\mathrm{H}_{1}$ : Tingkat suku bunga secara signifikan mampu mempengaruhi profitabilitas.

\section{Pengaruh Leverage Terhadap Profitabilitas}

Leverage yaitu keahlian perusahaan dalam melunasi kewajiban finansial jangka pendeknya dan jangka panjangnya atau menghitung seberapa besar perusahaan menggunakan hutang (Wiagustini, 2014:85). Debt to equity ratio ialah rasio yang dipakai untuk melihat perbandingan total hutang dengan modal (Kasmir, 2012:166). Kenaikan hutang dapat memengaruhi besar kecilnya laba yang didapat perusahaan. Semakin besar hutang yang dipakai dalam kegiatan operasional perusahaan seharusnya dapat mewujudkan laba yang optimal. Setiawan dan Triaryati (2016), Herdiani dkk. (2014), Lindayani dan Dewi (2016) mendapatkan bahwa leverage berpengaruh positif terhadap profitabilitas. Sementara itu, penelitian yang Enekwe et al (2014) dan Awan (2014) lakukan menyatakan bahwa 
leverage memiliki pengaruh negatif terhadap profitabilitas. Berdasarkan penelitian terdahulu, dapat disusun hipotesis sebagai berikut:

$\mathrm{H}_{2}$ : Leverage secara signifikan mampu mempengaruhi profitabilitas.

\section{Pengaruh Tingkat Suku Bunga Terhadap Return Saham}

Tingkat suku bunga yang meningkat akan mengakibatkan tingkat bunga tabungan meningkat, yang menyebabkan investor cenderung mengalihkan dananya dari saham ke tabungan atau deposito, sehingga banyak investor yang menjual saham dan mengalihkannya dananya ke pasar uang dengan asumsi permintaan saham tetap dan tingkat penawaran saham naik, sehingga harga saham menurun. Penelitian yang Utami et al. (2015), Khan et al. (2012), Dewi dkk. (2016) lakukan menyatakan bahwa tingkat suku bunga memiliki pengaruh negatif terhadap return saham. Sementara itu, penelitian yang Bararoh (2015) lakukan mendapatkan bahwa tingkat suku bunga berpengaruh positif terhadap return saham. Berdasarkan penelitian terdahulu, mampu disusun hipotesis yaitu:

$\mathrm{H}_{3}$ : Tingkat suku bunga secara signifikan mampu mempengaruhi return saham.

\section{Pengaruh Leverage Terhadap Return Saham}

Debt to Equity Ratio (DER) yang besar dapat menyebabkan risiko perusahaan tidak sanggup dalam membayar hutang yang dimilikinya semakin tinggi (Kasmir, 2012:158). Investor cenderung untuk menjauhi perusahaan yang mempunyai DER yang besar karena memiliki risiko perusahaan yang relatif besar. DER yang besar, memerlihatkan komposisi jumlah hutang yang perusahaan miliki lebih tinggi dibandingkan dengan total modal sendiri. Besarnya DER perusahaan dapat memberikan dampak yang besar pada beban perusahaan terhadap kreditur, 
yang menyebabkan perolehan laba menurun. Menurunnya laba perusahaan dapat menyebabkan harga saham perusahaan menurun, sehingga return yang didapat investor akan menurun pula. Penelitian yang dilakukan oleh Utami et al. (2015), Allozi and Obeidat (2016), dan Ghi (2016) yang menyatakan bahwa leverage berpengaruh negatif terhadap return saham. Sementara itu, penelitian yang Abdullah et al (2015) lakukan mendapatkan bahwa leverage berpengaruh positif terhadap return saham. Berdasarkan penelitian terdahulu, mampu disusun hipotesis yaitu:

$\mathrm{H}_{4}$ : Leverage secara signifikan mampu mempengaruhi return saham.

\section{Pengaruh Profitabilitas Terhadap Return Saham}

Return on equity (ROE) perusahaan yang semakin besar menggambarkan bahwa perolehan laba bersih yang didapat perusahaan meningkat, sehingga semakin bagus pula perusahaan tersebut di mata para investor (Setiawan dan Triaryati, 2016). Saham perusahaan yang banyak diinginkan oleh investor, mengakibatkan harga saham perusahaan naik, yang berakibat pada return yang diperoleh investor juga naik. Penelitian yang Khan et al. (2013) lakukan mendapatkan hasil dimana profitabilitas berpengaruh positif terhadap return saham. Hasil ini didukung dengan penelitian yang dilakukan oleh Bararoh (2015) dimana profitabilitas memiliki pengaruh positif terhadap return saham. Anwaar (2016) juga menemukan hasil yang serupa bahwa profitabilitas berpengaruh positif terhadap return saham. Berdasarkan penelitian terdahulu, mampu disusun hipotesis yaitu:

$\mathrm{H}_{5}$ : Profitabilitas berpengaruh positif dan signifikan terhadap return saham.

\section{Peran Profitabilitas dalam Memediasi Pengaruh Tingkat Suku Bunga Terhadap Return Saham}


Perubahan tingkat suku bunga akan mempengaruhi profitabilitas perusahaan (Maulida dkk, 2016). Tingkat suku bunga yang meningkat akan meningkatkan beban perusahaan, namun apabila perusahaan mampu mengatur pendanaan usahanya hingga menekan biaya-biaya yang dikeluarkan dan mampu meningkatkan penjualan maka akan meningkatkan laba perusahaan. Apabila laba yang diterima perusahaan lebih tinggi dibandingkan peningkatan tingkat suku bunga, dapat menaikkan laba bersih yang didapat dan profitabilitas perusahaan akan meningkat. Meningkatnya laba perusahaan akan menarik perhatian para investor untuk menginvestasikan dana yang dimilikinya, dengan demikian akan mempengaruhi harga saham perusahaan. Peningkatan harga saham perusahaan menyebabkan perolehan return mengalami peningkatan pula. Hasil penelitian yang Maringka et al. (2016), Sari (2013), dan Widyastuti et al (2017) lakukan menunjukkan bahwa profitabilitas signifikansi memediasi pengaruh tingkat suku bunga terhadap return saham. Berdasarkan penelitian terdahulu, mampu disusun hipotesis yaitu:

$\mathrm{H}_{6}$ : Profitabilitas secara signifikan mampu memediasi pengaruh tingkat suku bunga terhadap return saham.

\section{Peran Profitabilitas dalam Memediasi Pengaruh Leverage Terhadap Return Saham}

Perusahaan yang menggunakan hutang sebagai modal usahanya dan mampu mengoptimalkan operasi perusahaan akan mampu menaikkan laba dan nilai saham perusahaan. Nilai saham perusahaan yang besar menggambarkan return yang didapat para investor naik pula. Penelitian yang dilakukan oleh Setiawan dan Triaryati (2016), Al-fisah (2016), dan Nevada (2016) menunjukkan hasil bahwa 
profitabilitas signifikansi memediasi pengaruh leverage terhadap return saham. Berdasarkan penelitian terdahulu, dapat disusun hipotesis yaitu: $\mathrm{H}_{7}$ : Profitabilitas secara signifikan mampu memediasi pengaurh leverage terhadap return saham.

\section{METODE PENELITIAN}

Berdasarkan latar belakang sebelumnya, penelitian ini berlokasi di perusahaan sub sektor konstruksi bangunan di BEI. Jenis data yang dipakai dalam penelitian ini dapat dikategorikan menjadi dua, yaitu data kuantitatif dan data kualitatif. Data kuantitatif dari penelitian ini yaitu data-data keuangan pada laporan keuangan perusahaan sektor konstruksi bangunan di BEI serta data tingkat suku bunga SBI periode 2011-2015. Data kualitatif dari penelitian ini yaitu data perusahaan-perusahaan yang terdaftar di sub sektor konstruksi bangunan pada BEI periode 2011-2015. Kumpulan data penelitian merupakan data sekunder yang didapat dari pengumuman laporan keuangan yang menyampaikan informasi return saham, debt to equity ratio (DER), return on equity (ROE), dan annual report yang diakses pada website resmi BEI yaitu www.idx.co.id, serta tingkat suku bunga selama periode pengamatan yang dimuat dalam website www.bi.go.id. Berdasarkan pembahasan sebelumnya, dapat dijelaskan yang digunakan metode dalam penelitian ini yaitu menggunakan dua variabel independen yang terdiri dari Tingkat Suku Bunga $\left(\mathrm{X}_{1}\right)$ dan Leverage $\left(\mathrm{X}_{2}\right)$, satu variabel mediasi adalah Profitabilitas (M), dan satu variabel dependen adalah Return Saham (Y). Berdasarkan penjelasan sebelumnya, objek penelitian yang digunakan diantaranya 
Return Saham, Profitabilitas yang diproksikan dengan Return on Equity (ROE), dan Leverage yang diproksikan dengan Debt to Equity Ratio (DER) perusahaan yang terdapat pada sub sektor konstruksi bangunan periode 2011-2015, serta Tingkat Suku Bunga periode 2011-2015.

Populasi dari penelitian ini ialah tiga belas perusahaan yang dimasukkan ke dalam sub sektor konstruksi bangunan di BEI sesuai publikasi www.idx.co.id dan sampel sebanyak tujuh perusahaan dengan memakai metode purposive sampling. Teknik analisis data menggunakan uji asumsi klasik, analisis jalur, dan uji sobel.

\section{HASIL DAN PEMBAHASAN}

Berdasarkan data yang diperoleh dengan metode pengumpulan data didapatkan deskripsi data tentang variabel penelitian seperti pada tabel berikut.

\section{Hasil Uji Asumsi Klasik}

Tabel 2.

Uji Normalitas

\begin{tabular}{ccc}
\hline Model & Sig. & Keterangan \\
\hline 1 & 0,054 & Normal \\
2 & 0,054 & Normal \\
\hline
\end{tabular}

Sumber: Data Diolah, 2017

Pada Tabel 2. menunjukkan hasil angka model persamaan yang diuji dengan nilai Sig. sebesar 0,054 > 0,05. Dari perhitungan tersebut menjelaskan angka dalam model regresi terdistribusi normal.

Tabel 3.

Uji Multikolinearitas

\begin{tabular}{ccc}
\hline Variabel & VIF & Keterangan \\
\hline Tingkat Suku Bunga & 1,003 & Nonmultikolinearitas \\
Leverage & 1,003 & Nonmultikolinearitas \\
\hline
\end{tabular}


Pada Tabel 3. Menunjukkan nilai VIF lebih kecil dari 10. Dari nilai tersebut menjelaskan gejala nonmultikolinearitas.

Tabel 4.

Uji Autokorelasi

\begin{tabular}{cc}
\hline Model & Durbin-Watson \\
\hline 1 & 1,951 \\
2 & 2,203 \\
\hline
\end{tabular}

Sumber: Data Diolah, 2017

Tabel 4. menunjukkan angka DW (Durbin-Watson) pada model 1 sebesar 1,951 dan model 2 sebesar 2,203 berada pada daerah nonautokorelasi.

Tabel 5.

Uji Heteroskedastisitas Persamaan 1

\begin{tabular}{cccc}
\hline Variabel & $\mathrm{t}$ & Sig. & Keterangan \\
\hline Tingkat Suku Bunga & 0,015 & 0,988 & Nonheteroskedastisitas \\
Leverage & $-1,389$ & 0,175 & Nonheteroskedastisitas \\
\hline
\end{tabular}

Sumber: Data Diolah, 2017

Tabel 6.

Uji Heteroskedastisitas Persamaan 2

\begin{tabular}{cccc}
\hline Variabel & $\mathrm{t}$ & $\mathrm{Sig}$. & Keterangan \\
\hline Tingkat Suku Bunga & 0,700 & 0,489 & Nonheteroskedastisitas \\
Leverage & 1,264 & 0,216 & Nonheteroskedastisitas \\
Profitabilitas & $-0,243$ & 0,809 & Nonheteroskedastisitas \\
\hline
\end{tabular}

Sumber: Data Diolah, 2017

Berdasarkan Tabel 5. dan Tabel 6. menjelaskan nilai Sig. Tingkat Suku Bunga, Leverage, dan Profitabilitas di atas 0,05 sehingga menjelaskan gejala nonheteroskedastisitas.

\section{Hasil Analisis Jalur}

Tabel 7.

Analisis Jalur Persamaan Regresi 1

\begin{tabular}{|c|c|c|c|c|c|c|}
\hline \multirow{2}{*}{\multicolumn{2}{|c|}{ Model }} & \multicolumn{2}{|c|}{$\begin{array}{l}\text { Unstandardized } \\
\text { Coefficients }\end{array}$} & \multirow{2}{*}{$\begin{array}{c}\text { Standardized } \\
\text { Coefficients } \\
\text { Beta }\end{array}$} & \multirow[t]{2}{*}{$\mathbf{T}$} & \multirow[t]{2}{*}{ Sig. } \\
\hline & & B & Std. Error & & & \\
\hline \multirow[t]{3}{*}{1} & (Constan) & 2,320 & 7,122 & & 0,326 & 0,747 \\
\hline & Tingkat Suku Bunga & 2,149 & 0,997 & 0,289 & 2,156 & 0,039 \\
\hline & DER & 0,022 & 0,005 & 0,601 & 4,485 & 0,000 \\
\hline
\end{tabular}


Sumber: Data Diolah, 2017

Pada Tabel 7. mampu disusun persamaan struktural yaitu:

$M=0,289 X_{1}+0,601 X_{2}$

Berdasarkan persamaan tersebut, mampu dijelaskan bahwa nilai $\beta_{1}$ adalah 0,289 mempunyai arti bahwa tingkat suku bunga berpengaruh signifikan terhadap profitabilitas. Nilai $\beta_{2}$ adalah 0,484 mempunyai arti bahwa leverage berpengaruh signifikan terhadap profitabilitas.

Tabel 8.

Analisis Jalur Persamaan Regresi 2

\begin{tabular}{|c|c|c|c|c|c|c|}
\hline \multirow{2}{*}{\multicolumn{2}{|c|}{ Model }} & \multicolumn{2}{|c|}{$\begin{array}{l}\text { Unstandardized } \\
\text { Coefficients }\end{array}$} & \multirow{2}{*}{$\begin{array}{c}\text { Standardized } \\
\text { Coefficients } \\
\text { Beta }\end{array}$} & \multirow[t]{2}{*}{$\mathbf{T}$} & \multirow{2}{*}{ Sig. } \\
\hline & & B & Std. Error & & & \\
\hline \multirow[t]{4}{*}{1} & (Constan) & $-1,711$ & 0,802 & & $-2,132$ & 0,410 \\
\hline & Tingkat Suku Bunga & 0,263 & 0,120 & 0,355 & 2,196 & 0,036 \\
\hline & DER & 0,001 & 0,001 & 0,401 & 2,082 & 0,046 \\
\hline & Profitabilitas & 0,004 & 0,020 & 0,035 & 0,177 & 0,861 \\
\hline
\end{tabular}

Sumber: Data Diolah, 2017

Pada Tabel 7. mampu disusun persamaan struktural yaitu:

$\mathrm{Y}=0,355 \mathrm{X}_{1}+0,401 \mathrm{X}_{2}+0,035 \mathrm{M}$

Berdasarkan persamaan tersebut, mampu dijelaskan bahwa nilai $\beta_{1}$ adalah 0,355 mempunyai arti bahwa tingkat suku bunga berpengaruh signifikan terhadap return saham. Nilai $\beta_{2}$ adalah 0,401 mempunyai arti bahwa leverage berpengaruh signifikan terhadap return saham. Nilai $\beta_{3}$ adalah 0,035 mempunyai arti bahwa profitabilitas berpengaruh signifikan terhadap return saham.

Berdasarkan model persamaan diagram jalur dapat dibentuk diagram koefisien jalur, namun terlebih dahulu perlu dicari nilai standar error yaitu:

$\mathrm{e}_{1}=\sqrt{1-\mathrm{R}_{1}{ }^{2}}=\sqrt{1-0,426}=0,574$ 
$\mathrm{e}_{2}=\sqrt{1-\mathrm{R}_{1}{ }^{2}}=\sqrt{1-0,296}=0,704$

Jika dimasukkan ke dalam bentuk diagram koefisien jalur, akan tampak pada Gambar 2. sebagai berikut:

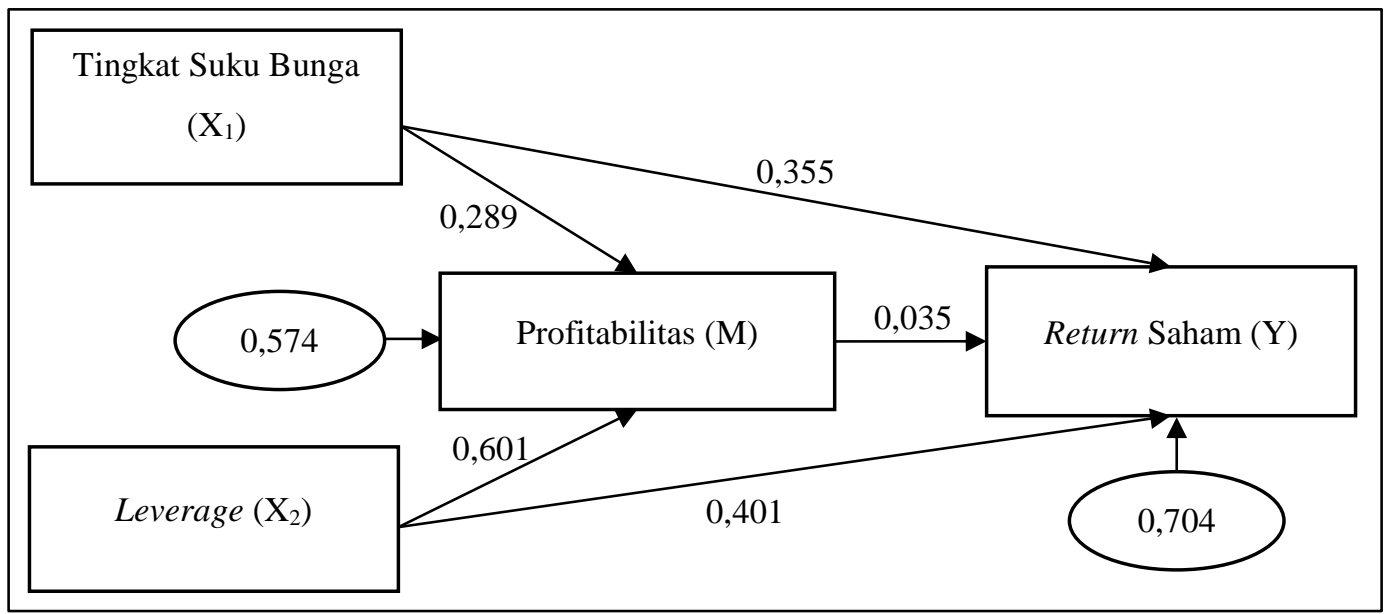

Gambar 2. Diagram Koefisien Jalur

Pengaruh variabel tingkat suku bunga $\left(\mathrm{X}_{1}\right)$ dan leverage $\left(\mathrm{X}_{2}\right)$ terhadap return saham (Y) melalui profitabilitas sebagai variabel perantara (M):

$$
\begin{aligned}
\text { indirect effect } & =\beta_{1} \times \beta_{5} & & =\beta_{2} \times \beta_{5} \\
& =0,289 \times 0,035 & & =0,601 \times 0,035 \\
& =0,010 & & =0,021
\end{aligned}
$$

Total pengaruh variabel tingkat suku bunga dan leverage terhadap return saham melalui profitabilitas sebagai berikut:

$$
\begin{aligned}
\text { total effect } & =\beta_{3}+\left(\beta_{1}\right) \times\left(\beta_{5}\right) \\
& =0,355+(0,289 \times 0,035)=0,365 \\
& =\beta_{4}+\left(\beta_{2}\right) \times\left(\beta_{5}\right) \\
& =0,401+(0,601 \times 0,035)=0,422
\end{aligned}
$$


Langkah selanjutnya dapat diuraikan hubungan antar variabel penelitian secara simultan. Pada Tabel 9. dan Tabel 10. menunjukkan hasil perhitungan uji simultan struktur 1 dan struktur 2 yaitu:

Tabel 9.

Hasil Uji Simultan Struktur 1

\begin{tabular}{llccccc}
\hline \multicolumn{2}{c}{ Model } & Sum of Squares & df & Mean Square & F & Sig. \\
\hline $1 \quad$ Regression & 309,937 & 2 & 154,969 & 11,893 & $0,000^{\text {a }}$ \\
Residual & 416,981 & 32 & 13,031 & & \\
\multicolumn{2}{l}{ Total } & 726,919 & 34 & & & \\
Sumber: Data Diolah, 2017 & & & &
\end{tabular}

Berdasarkan hasil uji simultan struktur 1 di Tabel 9. menghasilkan F hitung senilai 11,893 dengan nilai Sig. $0,000<0,05$. Dengan koefisien signifikan $\leq 0,05$ berarti variabel tingkat suku bunga dan leverage secara simultan berpengaruh terhadap profitabilitas.

Tabel 10.

Hasil Uji Simultan Struktur 2

\begin{tabular}{llccccc}
\hline \multicolumn{1}{c}{ Model } & Sum of Squares & df & Mean Square & F & Sig. \\
\hline 1 & Regression & 2,143 & 3 & 0,714 & 4,334 & 0,012 \\
Residual & 5,11 & 31 & 0,165 & & \\
Total & 7,253 & 34 & & & \\
\hline
\end{tabular}

Sumber: Data Diolah, 2017

Berdasarkan hasil uji simultan struktur 2 di Tabel 10. menghasilkan F hitung senilai 4,334 dengan nilai Sig. 0,012 <0,05. Dengan koefisien signifikan $\leq 0,05$ berarti variabel tingkat suku bunga, leverage dan profitabilitas secara simultan berpengaruh terhadap return saham.

Tabel 11

Pengaruh Langsung dan Pengaruh Tidak Langsung serta Pengaruh Total Tingkat Suku Bunga $\left(\mathrm{X}_{1}\right)$, Leverage $\left(\mathrm{X}_{2}\right)$, Profitabilitas $(\mathrm{M})$, dan

Return Saham (Y) 


\begin{tabular}{ccccc}
\hline Pengaruh Variabel & $\begin{array}{c}\text { Pengaruh } \\
\text { Langsung }\end{array}$ & $\begin{array}{c}\text { Sig. } \\
(\text { sig = 5\%) }\end{array}$ & $\begin{array}{c}\text { Pengaruh Tidak Langsung } \\
\text { (melalui Profitabilitas) }\end{array}$ & $\begin{array}{c}\text { Pengaruh } \\
\text { Total }\end{array}$ \\
\hline $\mathrm{X}_{1} \longrightarrow \mathrm{M}$ & 0,289 & 0,039 & - & 0,289 \\
$\mathrm{X}_{2} \longrightarrow \mathrm{M}$ & 0,601 & 0,000 & - & 0,601 \\
$\mathrm{X}_{1} \longrightarrow \mathrm{Y}$ & 0,355 & 0,036 & 0,010 & 0,365 \\
$\mathrm{X}_{2} \longrightarrow \mathrm{Y}$ & 0,401 & 0,046 & 0,021 & 0,422 \\
$\mathrm{M} \longrightarrow \mathrm{Y}$ & 0,035 & 0,861 & - & 0,035 \\
\hline
\end{tabular}

Sumber: Data Diolah, 2017

\section{Hasil Uji Sobel}

Hasil uji sobel pada signifikasi tidak langsung pengaruh tingkat suku bunga terhadap return saham melalui profitabilitas diperoleh $\mathrm{Z}$ ialah 0,2159 lebih kecil dari 1,96. Hasil ini menjelaskan variabel profitabilitas secara signifikan tidak dapat memediasi hubungan antara variabel tingkat suku bunga dengan variabel return saham.

Hasil uji sobel untuk signifikasi tidak langsung pengaruh leverage terhadap return saham melalui profitabilitas diperoleh $\mathrm{Z}$ ialah 1,1666 lebih kecil dari 1,96. Hasil ini menjelaskan variabel profitabilitas secara signifikan tidak dapat memediasi hubungan antara variabel leverage dengan variabel return saham.

\section{Pembahasan Pengaruh Setiap Variabel}

\section{Pengaruh Tingkat Suku Bunga Terhadap Profitabilitas}

Penelitian ini menemukan bahwa tingkat suku bunga terhadap profitabilitas mempunyai pengaruh positif yang signifikan. Hal ini menunjukkan meningkatnya tingkat suku bunga, maka profitabilitas perusahaan akan meningkat, karena perusahaan mampu meningkatkan penjualannya sehingga mendapatkan laba yang lebih besar dibandingkan kenaikan tingkat suku bunga, maka laba bersih yang didapat naik dan profitabilitas meningkat pula. Hasil dalam penelitian ini 
mendukung penelitian sebelumnya yang dilakukan oleh Khan and Sattar (2014), Malik et al. (2014), dan Ali (2015) yang menemukan bahwa tingkat suku bunga berpengaruh positif terhadap profitabilits.

\section{Pengaruh Leverage Terhadap Profitabilitas}

Hasil penelitian ini ditemukan bahwa leverage terhadap return saham mempunyai pengaruh yang positif dan signifikan. Hal ini memerlihatkan bahwa melalui pendanaan perusahaan yang menggunakan hutang dan mampu mengoptimalkan penggunaan hutang untuk kegiatan operasi perusahaan, maka keuntungan yang diperoleh perusahaan akan naik pula. Hasil penelitian ini selaras dengan teori trade-off yang menyebutkan bahwa leverage dan profitabilitas memiliki hubungan yang positif dengan asumsi keuntungan pajak lebih tinggi dibandingkan biaya-biaya yang dikeluarkan perusahaan. Perusahaan akan mendapatkan keuntungan yang tinggi apabila diikuti dengan meningkatnya tingkat hutang. Hasil dalam penelitian ini mendukung penelitian sebelumnya yang dilakukan oleh Setiawan dan Triaryati (2016), Tiara dkk. (2014), serta Lindayani dan Dewi (2016) yang menemukan bahwa leverage berpengaruh positif terhadap profitabilitas.

\section{Pengaruh Tingkat Suku Bunga Terhadap Return Saham}

Riset ini menemukan bahwa tingkat suku bunga dan return saham memiliki pengaruh yang positif dan signifikan. Hal ini memerlihatkan bahwa tingkat suku bunga yang besar, dapat membuat investor mencari saham perusahaan yang dapat menghasilkan laba tinggi dengan meramalkan laba setelah pajak perusahaan yang diprediksi bahwa di masa mendatang, perusahaan dapat memeroleh laba yang 
tinggi, maka investor melaksanakan investasi di perusahaan tersebut yang di masa mendatang akan meningkatkan return saham. Hasil penelitian ini selaras dengan teori keynes yang menyebutkan bahwa tingkat suku bunga yang tinggi akan mengakibatkan masyarakat menginvestasikan dana yang dimilikinya pada saham atau surat berharga lainnya (Sukirno, 2013:381). Hasil dalam penelitian ini mendukung penelitian sebelumnya yang dilakukan oleh Bararoh (2015) yang menyatakan bahwa tingkat suku bunga berpengaruh positif terhadap return saham.

\section{Pengaruh Leverage Terhadap Return Saham}

Hasil penelitian ini ditemukan bahwa leverage terhadap return saham memiliki pengaruh yang positif dan signifikan. Hal ini menunjukkan bahwa melalui penggunaan hutang, investor lebih tertarik dalam melakukan investasi, maka permintaan pada saham akan naik dan menyebabkan harga saham mengalami peningkatan pula yang nantinya akan meningkatkan return saham. Hasil ini sesuai dengan teori trade-off, dimana leverage dan nilai perusahaan memiliki hubungan yang positif dengan asumsi keuntungan pajak lebih tinggi dari biaya-biaya yang dikeluarkan perusahaan. Tingginya keuntungan yang didapat perusahaan akan menyebabkan investor tertarik untuk berinvestasi saham, sehingga menaikkan return saham perusahaan. Hasil dalam penelitian ini mendukung penelitian sebelumnya yang dilakukan oleh Abdullah et al. (2015) yang menyatakan bahwa leverage berpengaruh positif terhadap return saham.

\section{Pengaruh Profitabilitas Terhadap Return Saham}

Penelitian ini menemukan hasil bahwa profitabilitas terhadap return saham memiliki pengaruh yang positif tetapi tidak signifikan. Profitabilitas yang 
diproksikan dengan return on equity (ROE) memerlihatkan bahwa investor tidak mengambil keputusan untuk melakukan investasi hanya dengan melihat satu rasio profitabilitas saja, namun investor melihat rasio profitabilitas lainnya seperti profit margin dan return on equity (ROA). Hasil dalam penelitian ini mendukung penelitian sebelumnya yang dilakukan oleh Khan et al. (2013), Bararoh (2015) dan Anwaar (2016) yang menyatakan bahwa profitabilitas berpengaruh positif tidak signifikan terhadap return saham.

\section{Peran Profitabilitas dalam Memediasi Pengaruh Tingkat Suku Bunga Terhadap Return Saham}

Hasil dari uji sobel mendapatkan nilai Z sebesar 0,2159 lebih kecil dari standar yang ditetapkan yakni 1,96 yang berarti bahwa profitabilitas tidak mampu memediasi pengaruh antara tingkat suku bunga terhadap return saham. Hal ini berarti, dalam melakukan pengambilan keputusan berinvestasi investor lebih melihat perkembangan tingkat suku bunga dibandingkan dengan profitabilitas perusahaan, sehingga peran profitabilitas dalam memediasi pengaruh tingkat suku bunga terhadap return saham tidak signifikan. Hasil penelitian ini mendukung penelitian Maulida dkk (2016) yang menemukan hasil bahwa profitabilitas secara signifikan tidak mampu memediasi pengaruh tingkat suku bunga terhadap return saham.

\section{Peran Profitabilitas dalam Memediasi Pengaruh Leverage Terhadap Return Saham}

Hasil dari uji sobel mendapatkan nilai $\mathrm{Z}$ sebesar 1,1666 lebih kecil dari standar yang ditetapkan yakni 1,96 yang berarti bahwa profitabilitas tidak dapat memediasi pengaruh antara leverage terhadap return saham. Hal ini bermakna, 
dalam melakukan pengambilan keputusan berinvestasi investor lebih melihat perkembangan penggunaan hutang perusahaan dibandingkan dengan profitabilitas perusahaan. Investor dalam mengambil keputusan untuk berinvestasi tidak melihat dari satu rasio profitabilitas, tetapi menggunakan rasio profitabilitas lainnya, sehingga peran ROE dalam memediasi pengaruh DER terhadap return saham tidak signifikan. Hasil penelitian ini mendukung penelitian Kurniawan dkk (2016) yang menemukan hasil bahwa profitabilitas secara signifikan tidak mampu memediasi pengaruh leverage terhadap return saham.

\section{Implikasi Hasil Penelitain}

Hasil penelitian ini menyatakan bahwa tingkat suku bunga, leverage, dan profitabilitas memiliki pengaruh yang positif terhadap return saham. Hasil penelitian ini mendukung teori trade-off dan teori Keynes. Teori trade-off menyebutkan bahwa perusahaan yang mampu mengoptimalkan penggunaan hutangnya, maka akan meningkatkan profitabilitas perusahaan serta nilai perusahaan akan meningkat yang menyebabkan permintaan akan saham naik, sehingga hara saham meningkat dan return saham juga meningkat. Sedangkan teori Keynes menyebutkan bahwa tingkat suku bunga yang tinggi, dapat mengakibatkan masyarakat menginvestasikan dana yang dimilikinya pada surat-surat berharga lainnya. Hasil penelitian ini juga memberikan implikasi praktis bahwa tingkat suku bunga dan leverage berperan penting bagi perusahaan dan meningkatkan profitabilitas. Selain mampu meningkatkan profitabilitas, serta menaikkan permintaan saham mengakibatkan harga saham meningkat, return saham meningkat pula. 


\section{SIMPULAN DAN SARAN}

Pada penjelasan permasalahan, kajian teori dan hasil perhitungan yang telah dipaparkan, maka penelitian ini diambil kesimpulannya diantaranya Profitabilitas mampu dipengaruhi secara positif dan signifikan oleh tingkat suku bunga; (2) Profitabilitas mampu dipengaruhi secara positif dan signifikan oleh leverage; (3) Return saham mampu dipengaruhi secara positif dan signifikan oleh tingkat suku bunga; (4) Return saham dapat dipengaruhi secara positif dan signifikan oleh leverage; (5) Return saham dapat dipengaruhi secara positif dan signifikan oleh profitabilitas; (6) Profitabilitas secara signifikan tidak mampu memediasi pengaruh Tingkat Suku Bunga terhadap Return Saham; (7) Profitabilitas secara signifikan tidak mampu memediasi pengaruh Leverage terhadap Return Saham.

Saran yang bisa diajukan yang sesuai dengan kesimpulan yang diperoleh dalam penelitian ini diantaranya (1) Hasil riset ini diharapkan mampu mempersembahkan informasi pada investor untuk mengambil pertimbangan investasi di pasar modal; (2) Hasil riset ini diharapkan mampu mempersembahkan informasi kepada perusahaan untuk mengambil pertimbangan dalam menaikkan kinerja perusahaan; (3) Hasil riset ini diharapkan mampu dijadikan referensi untuk menambahkan bukti empiris pada manajemen keuangan mengenai faktor-faktor yang memengaruhi return saham. Jadi penelitian selanjutnya disarankan untuk mengganti atau menambahkan variabel lain yang mampu memengaruhi return saham serta menggunakan jenis perusahaan lain untuk diteliti selanjutnya. 
I Gusti Ngurah Wira Aditya, Peran Profitabilitas dalam Memediasi...

\section{REFERENSI}

Abdullah, Mohammad Nayeem., Kamruddin Parvez., Tarana Karim., and Rahat Bari Toohen. 2015. The Impact of Financial Leverage and Market Size on Stock Returns on the Dhaka Stock Exchange: Evidence from Selected Data in the Manufacturing Sector. International Journal of Economics, Finance and Management Science, 3 (1): 10-15.

Acheampong, Prince., Evans Agalega., and Albert Kwabena Shibu. 2014. The Effect of Financial Leverage and Market Size on Stock Return on the Ghana Stock Exchange: Evidence from Selected Stock in the Manufacturing Sector. International Journal of Financial Research, 5 (1): 125-134.

Adiyadnya, I Nyoman Sidhi., L.G. Sri Artini., dan Henny Rahyuda. 2016. Pengaruh Beberapa Variabel Ekonomi Makro Terhadap Profitabilitas dan Return Saham Pada Industri Perbankan di BEI. E-Jurnal Ekonomi dan Bisnis Universitas Udayana, 5 (8): 2579-2608.

Al-Fisah, Mirza Chayatun. 2016. Profitabilitas Memediasi Pengaruh Struktur Modal Terhadap Nilai Perusahaan Properti yang Terdaftar di BEI. Jurnal Ilmu dan Riset Manajemen, 5 (5): 1-15

Ali, Muhammad. 2015. Macroeconomic Determinants of Islamic Banks Profitability in Pakistan: A Time Series Analysis. Journal of Business Strategies, 9 (2): 83-97.

Allozi, Nurah Musa and Ghassan S. Obeidat. 2016. The Relatioship between the Stock Return and Financial Indicators (Profitability and Leverage): An Empirical Study on Manufacturing Companies Listed in Amman Stock Exchange. Journal of Social Sciences (COES\&RJ-JSS), 5 (3): 408-424.

Anwaar, Maryyam. 2016. Impact of Firm's Performance on Stock Return (Evidence from Listed Companies of FTSE-100 Index London, UK). Global Journal of Management and Business Research, 16 (1): 31-39.

Awan, Maria Rasheed. 2014. Impact of liquidity, leverage, inflation on firm profitability an empirical analysis of food sector of Pakistan. IOSR Journal of Business and Management, 16 (1): 104-112.

Bararoh, Tantri. 2015. Analysis of Fundamental Factors, Foreign Exchange and Interest Rate on Stock Return (Studies in Manufacturing Companies Listed on Indonesia Stock Exchange for 2011-2013 periods). International Journal of Business and Management Invention, 4 (2): 36-42.

Brigham, Eugene F., dan Joel F. Houston. 2011. Dasar-dasar Manajemen Keuangan. Jakarta: Salemba Empat.

Dewi, Gusti Ayu Ketut Chandni., Gede Merta Sudiartha. 2014. Pengaruh Price Earning Ratio, Dividend Payout Ratio, Return On Assets, Tingkat Suku 
Bunga SBI, serta Kurs Dollar AS Terhadap Harga Saham. E-Jurnal Ekonomi dan Bisnis Universitas Udayana, 3 (1): 129-148.

Dewi, Putu Ayu Rusmala., I.B Panji Sedana., dan L.G. Sri Artini. 2016. Pengaruh Tingkat Suku Bunga, Risiko Pasar, Debt to Equity Ratio, dan Price Earning Ratio Terhadap Return Saham pada Perusahaan Properti and Real Estate di Bursa Efek Indonesia. E-Jurnal Ekonomi dan Bisnis Universitas Udayana, 3 (3): 489-516.

Effendi, R., dan Sawitriyadi. 2013. Faktor-Faktor Penentu Ekspor Minyak Kelapa Sawit (Crude Palm Oil) Indonesia. Jurnal Ekonomi dan Bisnis, 8 (3): 44-67.

Enekwe, Chinedu Innocent., Charles Ikechukwu Agu., and Eziedo Kenneth Nnagbogu. 2014. The Effect of Financial Leverage on Financial Performance: Evidence of Quoted Pharmaceutical Companies in Nigeria. IOSR Journal of Economics and Finance (IOSR-JEF), 5 (3): 17-25.

Ganerse, I Made Brian., dan A.A.G. Suarjaya. 2014. Pengaruh Profitabilitas, Likuiditas Dan Ukuran Perusahaan Terhadap Return Saham Pada Perusahaan Food And Beverages Di Bursa Efek Indonesia. E-Jurnal Manajemen Universitas Udayana, 3 (6): 1620-1632.

Ghi, Tran Nha. 2016. The Impact of Capital Structure and Financial Performance on Stock Return of the Firms in HOSE. International Journal of Research and Review, 2 (6): 734-737.

Herdiani, Tiara., Darminto., dan MG. Wi. Endang NP. 2013. Pengaruh Financial leverage Terhadap Profitabilitas Studi Pada Perusahaan Manufaktur Yang Terdaftar di Bursa Efek Indonesia Periode 2009-2011. Jurnal Administrasi Bisnis, 5 (1): 1-8.

Kasmir. 2012. Analisis Laporan Keuangan. Jakarta: PT. Raja Grafindo Persada.

Khan, Wajid., Arab Naz., Madhina Khan., Waseem Khan Qaiser Khan., and Shabeer Ahmad. 2013. The Impact of Capital Structure and Financial Performance on Stock Returns "A Case of Pakistan Textile Industry". Middle-East Journal of Scientific Research, 16 (2): 289-295.

Khan, Waseem Ahmad., and Abdul Sattar. 2014. Impact of Interest Rate Changes on the Profitability of four Major Commercial Banks in Pakistan. International Journal of Accounting and Financial Reporting, 4 (1): 142-154.

Khan, Zohaib., Sangeen Khan., Lala Rukh., Imdadullah., and Wajeeh ur Rehman. 2012. Impact of Interest Rate, Exchange Rate and Inflation on Stock Returns of KSE 100 Index. International Journal of Economics Research, 3 (5): 142155.

Kurniawan, Teddy., Yuliani., dan Reza Ghasarma. 2016. Pengaruh Likuiditas, Financial Leverage, Aktivitas Terhadap Return Saham dengan Profitabilitas 
I Gusti Ngurah Wira Aditya, Peran Profitabilitas dalam Memediasi...

sebagai Variabel Mediasi. Jurnal Manajemen dan Bisnis Sriwijaya, 14 (1): 121-132.

Lindayani, Ni Wayan., dan Sayu Kt. Sutrisna Dewi. 2016. Dampak Struktur Modal dan Inflasi terhadap Profitabilitas dan Return Saham Perusahaan Keuangan Sektor Perbankan. E-Jurnal Manajemen Universitas Udayana, 5 (6): 52745303.

Mahmudah, Umrotul. 2016. Pengaruh ROA, Firm Size, dan NPM Terhadap Return Saham Pada Perusahaan Semen. Jurnal Ilmu dan Riset Manajemen, 5 (1): 115

Malik, Muhammad Faizan., Shehzad Khan., Muhammad Ibrahim Khan., and Faisal Khan. 2014. Interest Rate and Its Effect on Bank's Profitability. Journal of Applied Environmental and Biological Science, 4 (8): 225-229.

Maringka, Tonny Serfius., Moeljadi P., Atim Djazuli., and Kusuma Ratnawati. 2016. Leverage, Free Cash Flow, and Interest Rates Influence of Stock Return and Financial Performance as Intervening Variables (Study on Manufacturing Industry Listed in Indonesia Stock Exchange). International Journal of Business and Management Invention, 5 (2): 28-30.

Maulida, Alfiatul., Elok Sri Utami., dan Sumani. 2016. Pengaruh Kurs dan Suku Bunga SBI Serta Inflasi Melalui Return On Asset Terhadap Return Saham. Jurnal Relasi STIE Mandala Jember, 12 (2): 670-684

Nevada, Erick. 2016. Analisis Pengaruh Leverage, Likuiditas dan Aktivitas Terhadap Profitabilitas Serta Implikasinya Pada Nilai Perusahaan. Skripsi Sarjana Jurusan Manajemen Fakultas Ekonomi dan Bisnis Universitas Islam Negri Syarif Hidayahtullah, Jakarta.

Rismawati, N.M., dan I.M. Dana. 2014. Pengaruh Pertumbuhan Aset dan Tingkat Suku Bunga Sertifikat Bank Indonesia (SBI) Terhadap Kebijakan Dividen dan Nilai Perusahaan Pada Perusahaan Manufaktur di Bursa Efek Indonesia (BEI). E-Jurnal Manajemen Universitas Udayana, 3 (4): 988-1004.

Saputra, I Gede Agus Angga., dan I.B. Dharmadiaksa. 2016. Pengaruh Tingkat Suku Bunga, Nilai Tukar Rupiah, Leverage dan Profitabilitas pada Return Saham. E-Jurnal Akuntansi Universitas Udayana, 16 (2): 1007-1033.

Sari, Irni Ristika. 2012. Pengaruh Indikator Makro Ekonomi Terhadap ROE dan ROI serta Implikasinya Terhadap Harga Saham (Studi Kasus Pada Industri Semen di Bursa Efek Indonesia). Jurnal Ilmiah Ekonomi Bisnis. ISSN: 0853$862 X$.

Setiawan, Putu Beny Rivardi., dan Nyoman Triaryati. 2016. Peran Profitabilitas dalam Memediasi Pengaruh Leverage Terhadap Return Saham Pada Perusahaan Food And Beverages. E-Jurnal Manajemen Universitas Udayana, 5 (5): 2972-2999. 
Simiyu, Christine Nanjala., Lessah Ngile. 2015. Effect of Macroeconomic Variables on Profitability of Commercial Banks Listed in The Nairobi Securities Exchange. International Journal of Economics, Commerce and Management, 3 (4): 1-16.

Tandelilin, Eduardus. 2010. Portofolio dan Investasi Teori dan Aplikasi. Yogyakarta: Kanisius.

Utami, Widya Retno., Sri Hartoyo., dan Tubagus Nur Ahmad Maulana. 2015. The Effect of Internal and External Factors on Stock Return: Empirical Evidence from the Indonesian Construction Subsector. Asian Journal of Business and Management, 3 (5): 370-377.

Widyastuti, Maria., Hening Widi Oetomo., and Akhmad Riduwan. 2017. Working Capital and Macroeconomic Variables as Value Creation in Indonesian Textile Companies. International Journal of Business and Finance Management Research. pp. 7-16.

Wiagustini, Ni Luh Putu. 2014. Manajemen Keuangan. Denpasar: Udayana University Press.

$\underline{\text { www.duniainvestasi.com }}$ 